\title{
Game Development on Dap Based Physical Education Study (Developmentally Appropriate Practice) for Basic School Children
}

\author{
Ruben Pardamean Hutapea ${ }^{1}$, Nurhayati Simatupang ${ }^{2}$, Indra Kasih ${ }^{3}$ \\ 1,2,3 Universitas Negeri Medan, Indonesia \\ ruben92p.hutapea@gmail.com
}

\begin{abstract}
This study aims to develop games in physical education subjects in schools based on DAP (Developmentally Appropriate Practice). Then in this research will produce a product in the form of a game module with the concept of DAP (Developmentally Appropriate Practice) for basic locomotor motion. This type of research is development research based on the Borg and Gall Model. The trial subjects consisted of material experts, game experts, and Physical Education teachers at Imanuel Medan and Methodist 1 Medan elementary schools. The first stage of this model is the needs research stage, followed by the design stage and the third stage is development and implementation. In this stage all stages involve an evaluation and revision process. Material expert judgment is $89 \%$, for game experts by $90.8 \%$ and the results of the sports teacher assessment at stage I was $73.8 \%$ and at stage II was $86 \%$. Results The results of product appraisal have increased with a difference of significance of $12.2 \%$. This shows that the product developed on locomotor motion through game development based on DAP (Developmentally Appropriate Practice) is appropriate for use in the implementation of learning.
\end{abstract}

Keywords

DAP (developmentally appropriate practice); locomotor motion; game development

\section{Introduction}

In understanding the meaning of physical education we must also consider the relationship between play (play) and sport (sport), as a term that was previously popular and more frequently used in the context of daily activities. This understanding will help teachers or the community understands the role and function of physical education in a more conceptual way. Class II physical education learning materials in elementary school include learning locomotor motion. The locomotor motion material (walking, running, jumping) must be packaged in a game that is attractive to students and increases students' interest to always be active in implementing walking, running and jumping materials. Basically, basic human movements are walking, running, jumping and throwing. Elementary school students already have this basic form of movement. The locomotor motion according to Yudha (2000: 21) is a movement to move places, where certain body parts move or move places. Basic locomotor motion is one of the domains of fundamental basic movement. Based on the results of the first semester evaluation of the mastery of locomotor motion material (walking, running and jumping) is unsatisfactory because the percentage of the results of the assessment of road material is $70 \%$ success, the percentage of running material is $60 \%$ and the jumping material is only $60 \%$ (Source of the Immanuel Private Elementary School Physical Education Teacher 
Terrain as approximate percentage breakdown only). From these results it can be seen that there are still many mistakes students make in locomotor motion, including there are still the wrong way of walking students, such as when walking, students walk with their legs opened too wide, the body is too bent, the position of the legs is less straight,According to Engkos Kosasih (1992: 4), he argues that physical education, sports and health, is education that actualizes the potential for human activity in the form of action and work to be given form, content and direction towards personality roundness in accordance with humanitarian ideals. It also states the meaning of physical education in the Ministry of National Education (2003: 6) Physical education is an educational process that utilizes physical activity and is planned systematically aimed at improving individuals organically, neuromuscularly, perceptually, cognitive, social and emotional. Physical education treats the child as a whole, total being, rather than simply considering him as someone who is separate from his physical and mental qualities. In fact, physical education is a very broad field of study. His point of interest is the improvement of human movement. One of the education related to sports is Physical Education, Sports, and Health (Penjasorkes). Physical education is one that uses physical activity. Bucher (1983: 13) states that "physical education is an integral part of the entire educational process, which has the goal of developing citizens physically (physically), mentally, emotionally, and through social activities that have been chosen to realize these goals.

Professional teachers should be able to convey the mission of physical education through their duties and obligations. In order for the task to be successful, as a student servant, an educator in teaching must be able to adapt to the varied and heterogeneous needs of students. Because every student has different learning objectives in following physical education. This difference in purpose will of course give birth to a different effort in following physical education. It all depends on the motives that exist in each student. This motive will later provide a strength that can encourage students to behave in order to realize the goals they want to achieve. The urge that makes students behave in a directed manner is called motivation. (Arsani et al, 2020)

Physical Education Sport and health is a subject given at a particular school level which is one part of overall education that prioritizes physical activity and fostering alife healthyfor growth and development of physically, mentally, socially and emotionally that is harmonious, harmonious and balanced (Depdiknas, 2006: 131). In general secondary education units that serve students with special needs, of course, require special handling in providing the learning process (Muchtar, 2020).

The goals of physical education are generally declassified into four development goals, namely: physical development. This goal is related to the ability to carry out activities that involve physical strengths from various organs of a person's body (physical fitness), movement development, this goal is related to the ability to move effectively, efficiently, smoothly, beautifully, and perfectly (full skill), mental development. This goal is related to the ability to think and interpret all knowledge about physical education into the environment, social development. This goal is related to the ability of students to adapt to a group or society. (Suherman in Birri, 2020)

According to Lumintuarso (2013: 6) multilateral motion is an amalgamation of various basic movements and basic movements of sports skills. Basic motion is divided into three main types of motion, namely locomotor motion, non-locomotor motion, and manipulative motion. Locomotor motion is the movement of the whole body through a room or a certain distance such as walking, running, jumping and so on, while non-locomotor motion is a motion where only parts of the body move such as pushing, pulling, leaning and manipulative movements are skill movements that use equipment. such as throwing, catching, hitting, kicking, volleying and 
others. According to Bompa (1999: 31) multilateral which is called multiskill or in German is called "vieleseitige" is the development of various motor skills and abilities (motor ability) with the adaptation of various training load needs to develop overall adaptation. Multilateral according to Yudanto (2005: 68) is a development that is comprehensive, not only covering physical aspects. Saputra (2001: 9) states that multilaterals are related to physical activity and comprehensive body movement which has implications for the body to be healthy and fit.

\section{Research Methods}

This research on game development in physical education subjects based on DAP (Developmentally Appropriate Practice) consists of 7 stages, with the steps in the design description of the explanation and aligned with the actual research objectives and conditions, as illustrated clearly in the following figure:

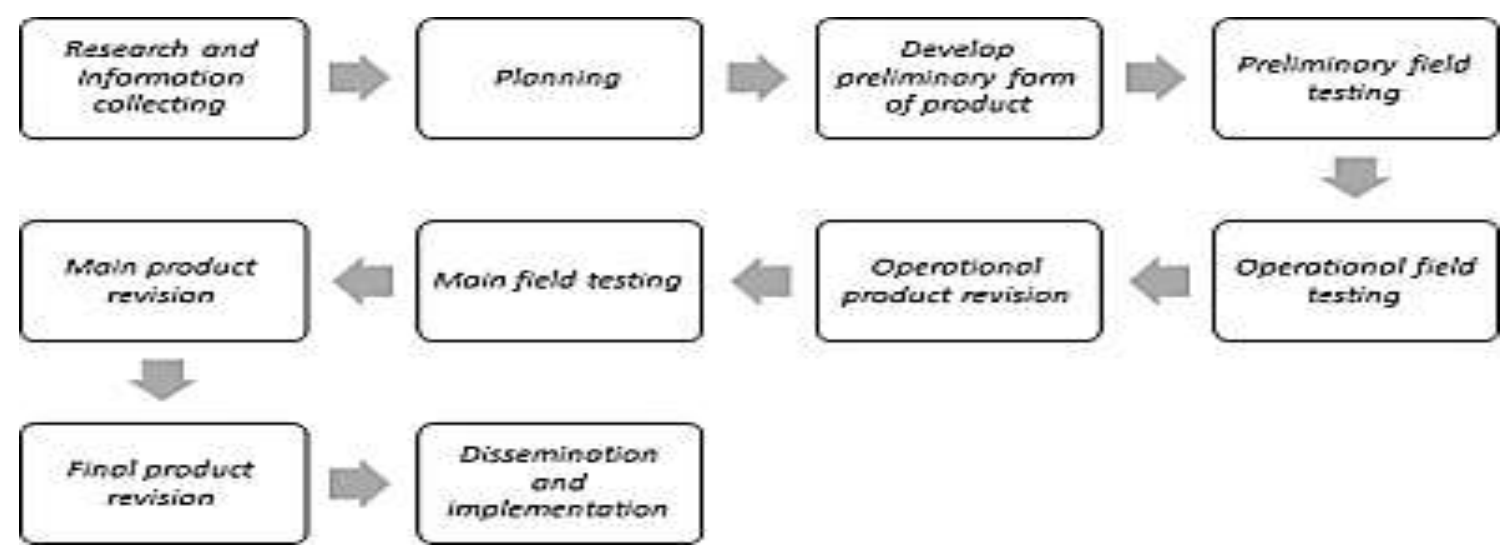

Figure 1. Development Research Stages and Steps

\section{Planning and Modeling}

Whereas for designing game development products in physical education subjects based on DAP (Developmentally Appropriate Practice) which has the following steps:

1) Research and information collecting: study of literature related to the problem under study, and preparation to formulate a research framework. In this study the steps taken by the researcher were:

- Collecting information from SD Methodist 1 Medan and SD Immanuel Medan regarding the learning outcomes of locomotor basic motion and games in physical education subjects conducted by teachers.

- Then interview the physical education teacher

- Collect literature.

2) Planning: formulate skills and expertise related to the problem, determine the objectives to be achieved at each stage, and if possible / necessary carry out a limited feasibility study. In this research the planning stages are:

- Collecting supporting journals about DAP and locomotors.

- Collect supporting books.

- Tracing the needs in the field (SD) with the game to be developed.

3) Develop preliminary form of product; developing initial forms of the product to be produced, preparation of supporting components, preparing guidelines and manuals, and evaluating the appropriateness of supporting tools. The steps in this research include:

- Determine the product design to be developed (hypothetical design), 
- Determine the research facilities and infrastructure needed during the research and development process,

- Determine the stages of the design test implementation in the field;

- Determine the job description of the parties involved in the research. Determine experts in research. Expert review consisting of 5 learning experts, 5 game experts and 5 material experts.

- PJOK teachers are given an understanding of the flow of the game in order to be able to understand the concept of the game, understand the objectives of the game and understand the value of the game. Researchers provide an explanation with the concept in detail.

4) Preliminary field testing: conduct initial field trials on a limited scale. by involving as many as 6-12 subjects. In this step, data collection and analysis can be done by means of interviews, observations or questionnaires. This step is a limited product test which includes:

- Conduct initial field tests on product designs where game products in physical education subjects based on DAP are first brought to experts,

- Then the researchers conducted small group trials on students of SD Methodist 1 Medan as many as 10 students.

- Conducted an assessment of students of SD Methodist 1 Medan.

5) Main product revision: make improvements to the initial product produced based on the initial trial results. This improvement is very likely to be done more than once, according to the results shown in the limited trial, so that the main product (model) draft is ready to be tested more widely. Revision II is a revision based on the opinions, difficulties and desires of the users. Limited field test revision which is an improvement to a model or

6) Design based on a limited field test. Revision III is a revision based on the opinions and input of experts. The steps in this research are:

- Products brought to experts (expert PJOK teachers, game experts and material experts)

- The research video was brought to the experts (PJOK teacher experts, game experts and material experts).

- Revision and ratification sheets are brought to experts (expert PJOK teachers, game experts and material experts)

- The results of the study were in the form of student data reduction brought to the experts (expert PJOK teachers, game experts and material experts).

- The researcher does what becomes the expert's revision.

7) Main field testing: the main trial involving all students. (1) conducting initial field tests on product designs, (2) limited in nature, both in substance of design and parties involved, and (3) preliminary field tests are carried out repeatedly in order to obtain a feasible design, both substance and methodology. The steps in this research are:

- Games in physical education subjects were tried out on a large scale on 20 Immanuel Medan students.

- Researchers document

8) Operational product revision: make improvements / improvements to the results of wider trials, so that the product being developed is already an operational model design that is ready to be validated. Revision of Broader Field Test Results: this step is the second improvement after a wider field test is carried out than the first field test. The steps in this research are:

- Large group trial products are brought to experts (expert PJOK teachers, game experts and material experts) 
- Large group trial research videos brought to the experts (expert PJOK teachers, game experts and material experts)

- Revision and ratification sheets are brought to experts (expert PJOK teachers, game experts and material experts)

- The results of the large group trial research in the form of student data reduction were brought to the experts (PJOK teacher experts, game experts and material experts)

- The researcher does what becomes the expert's revision.

\section{Discussion}

Development research is a research that is based on the making of a product that begins with observational analysis, conducting needs analysis, designing product development drafts, and product testing (Riza, 2015: 23). According to Harun (2017: 170) also states that research and development is an effort to develop a product that does not exist or to improve existing products to solve existing problems or to apply findings and theories to solve existing problems as needed.

So this research is a type of research and development. The results of this research and development are locomotor basic motion learning module products based on DAP (Developmentally Appropriate Practice). There are several problems underlying the development of locomotor basic motion learning modules based on DAP (Developmentally Appropriate Practice). These problems include:

The development stages in this study were guided by The research and development steps of Brog and Gall are ten steps which are simplified into nine steps including the following: "1) Research and information collecting, 2) Planning, 3) Develop preliminary form of product, 4) Preliminary field testing, 5 ) Main product revision, 6) Main field testing, 7) Operational product revision, 8) Operational field testing, 9) Final product revision, 10) Dissemination and implementation ".

The factors that underlie the simplification of this research are: Lack of development of game concept material carried out by physical education teachers, limited space for students, and physical education learning is not in accordance with DAP Developmentally Appropriate Practice) where for low classes teachers usually ignore this.

1. Limited time

This research and development is carried out up to ten stages and will require a relatively long and long process. Therefore, through this simplification into four stages of research and development, the research is completed in a shorter time, but is still efficient and effective in the process and results.

2. Cost Limitations

A relatively large cost is needed if this research and development is carried out in ten stages. Therefore, through simplification of the research phase, this research can be completed at a relatively lower cost.

3. Expert Opinion

Borg \& Gall (1983: 792) argue:

"If you plan to do an R \& D project for a thesis or dissertasion, you sholud keep these cautions in mind. It is best to undertake a small-scale project that involves a limited amount of the original instruction design. Also, unless you have substantial financial resources, you will need to avoid expensive instructional media such as 16- $\mathrm{mm}$ film and synchronized slidetape. Another way to scale down the project is to limit development to just a few step of the R \& D cycle". 
(If you are planning to undertake an $\mathrm{R} \& \mathrm{D}$ project for a thesis or dissertation, you should carefully memorize it. It is best to undertake a small-scale project that involves a limited number of original instructional designs. Additionally, unless you have large financial resources, you should should avoid expensive instructional media such as $16-\mathrm{mm}$ film and synchronized slidetape. Another way of scaling down a project is to limit development to just a few steps of $R \& D$ ).

The four stages of research and development include: a. Introduction Stage (research and information collecting), b. Planning and Design or Product stage (planning and developing preliminary form of product), c. The teacher trial phase (preliminary field testing and main field testing), d. Product Revision (Operational product revision).

The preliminary stage includes searching for potential research problems and information, potential problems and information collected so as to obtain a research data. After completing the Preliminary Stage (research and information collecting), enter the planning and design stage or the product (planning and develop preliminary form of product), the basic locomotor motion learning module product based on DAP (Developmentally Appropriate Practice), make an expert assessment instrument material, game expert, and product assessment by the teacher regarding the product being developed.

After making product designs and assessment instruments for material experts, game experts, and product assessments by product teachers developed. The assessment instrument is validated first by a validator who has been assigned by the postgraduate study program at the State University of Medan. The instrument validator in this study isfatherDr. Budi Valianto, M.Pd. andfatherDr. Albadi Sinulingga, M.Pd. After completing the instrument validator

The initial product design is validated to the respective experts who are competent in the field of material and games. Material experts who make judgments about the productfrom the material aspect validated by Dr. Ibrahim, S.Pd., M.Pd, Mr. Dr. Samsudin Siregar, M. Or, and Mr Drs. Suharjo. M.Pd and game expert validation were validated by Mr. Samsudin Tarigan, S.Pd. M.Pd, Bapak Ramadan, S.Pd., M.Pd., AIFO. And Mr. Sabar Surbakti, S.Pd. M.Orall these experts have competence in their fields and are in accordance with the characteristics of the product being developed.

At this validation stage the products that have been made by the researcher are validated in order to obtain suggestions and input from experts in accordance with the initial product design in the form ofBasic locomotor motion learning module based on DAP (Developmentally Appropriate Practice). After obtaining suggestions and input regarding the products made, sfurthermore, the product was shown the repair again to the material and game experts.

The result of the overall average percentage of the material expert's assessment is $89 \%$ with the criteria "very good", hthe result of expert validation of PJOK learning games obtained a percentage of the assessment of $90.8 \%$ with the criteria "very good". SOverall it can be determined that the product being developed is "feasible" with the meaning that it can be "used" after going through previous improvements and refinements.

After the material expert and game expert validation stage, the development was continued with initial field trials, namely stage I with 5 teachers and stage II with 10 teachers. The test in stage I was carried out by 5 peoplePhysical education teachers obtained results of $73.8 \%$ with the criteria "sufficient". Then in the results of the phase II trial after the product had improved in stage I then in stage II it was tested by increasing the number of samples totaling 10 teachers to assess the products that had been developed.

The results of testing in stage II obtained an assessment percentage of $86 \%$ with the criteria "very good. It can be concluded that the results of the assessment of material experts, game experts and teacher assessments are aboutThe product is a locomotor basic motion learning module based on DAP (Developmentally Appropriate Practice). 
Products that have been declared very worthy Based on the results of the expert's assessment of the material, games and assessments that the teacher has done with stage I and stage II with a significance scale of $12.2 \%$, it proves that the product developed is suitable for use in teaching locomotor motion to second grade students of Imanuel Medan elementary school and school basic Methodist 1 Medan.

\section{Conclusion}

Based on the results of research and discussion of the results of research on the development of locomotor based motion learning modules DAP (Developmentally Appropriate Practice) in grade II elementary school students Imanuel Medan and Methodist 1 Medan, it can be concluded as follows:

a. This study develops and produces a learning module based on the concept of DAP (Developmentally Appropriate Practice). on the basic motion material for locomotor for grade II elementary school Imanuel Medan and Methodist 1 Medan.

b. The feasibility of teaching materials from material experts and game experts obtained very good criteria. average acquisition of material experts in the module obtains an average of $89 \%$ with "very good" criteria, and $90.8 \%$ of gamers with "very good" criteria.

c. The results of the teacher's responses regarding the developed module which were assessed by five Physical Education teachers in stage I at Imanuel Medan elementary school teachers obtained an average acquisition of $73.8 \%$ on the "sufficient" criteria then in phase II in schools and Methodist 1 Medan with a sample two times greater than the previous results obtained an average presentation of $86 \%$ with the criteria "very good" with a scale of significance of $12.2 \%$ from the previous test results.

\section{Suggestion}

Based on the conclusions and implications above, this study still has many shortcomings and many things that still need to be studied, especially the assessment of this module only reaches the teacher. This occurred due to the Covid-19 virus pandemic outbreak. Based on the results of research on game development based on DAP (Developmentally Appropriate Practice), the researcher puts forward the following suggestions:

1. For schools, it is hoped that they can use a learning module through a game model with the concept of DAP (Developmentally Appropriate Practice) as an alternative in teaching activities in physical education in the basic locomotor motion material. Because the gamebased learning model invites students to learn fun while playing.

2. For teachers Teachers can take advantage of learning modules about locomotor motion through games based on DAP (Developmentally Appropriate Practice). Teachers can also make other developments by developing appropriate learning materials.

3. For further researchers, they can develop different materials or the same concept based on DAP (Developmentally Appropriate Practice). With much greater testing and up to product implementation in the field. 


\section{References}

Abdulkadir Ateng. (1992). Sports Education. Jakarta: IKIP Jakarta.

Abdul Kadir Ateng. (1992). Principles and Foundations of Physical Education. Ministry of Education and Culture, Directorate General of Higher Education, Educational Personnel Development Project.

Adang Suherman. (2000). Basics of Physical Education. Ministry of Education and Culture, Directorate General of Primary and Secondary Education, Section D-III Junior Secondary Teacher Upgrading Project.

Agung Sunarno. (2017). Philosophy of Sports. Medan: LARISPA INDONESIA.

Albadi Sinulingga. (2012). Basic Theory of Motor Control in Physical Education and Sports at Early Age. Medan: Unimed Press.

Amung Ma'mun and Yudha M. Saputra. (1999). Development of Motion and Learning Motion. Ministry of Education and Culture, Directorate General of Pendas, Part of the Equivalent D-III Junior High School Teacher Upgrading Project

Arsani, et al. (2020). Differences in Motivational Orientation in Physical Education in terms of Gender Differences. Budapest International Research and Critics in Linguistics and Education (BirLE) Journal. P. 1428-1434

Aunurrahman. (2012). Learning and Learning. Bandung: CV Alfabeta.

Birri, M. et al. (2020). Development of Traditional Sport Game Model "Bentengan" for Student's Physical Fitness in Sports and Health Physical Education Learning (Case Study on Class IV MI Students of Maduran Lamongan District). Budapest International Research and Critics in Linguistics and Education (BirLE) Journal. P. 1614-1622.

Borg. W. R \& Gall, MD. (1983). Educational Research An Introduction. New York: Longman. BSNP. (2006). Content Standards of Senior High School / Vocational High School. Jakarta: Depdikbud.

Bucher, CA. (1983). Foundations of Physical Education and Sport. London: Mosby Company. Bredekamp, Sue. (1987). Developmentally Appropriate Practice in Early Childhood Programs Serving Children from Birth Throught Age 8. Wasington: NAEYC.

B, E, Rahantoknam. (1998). Learning Motor Theory and Its Application in Physical Education and Sports. Jakarta: Dikti, P2LPTK.

Coverage. (1993). Play Theory. Jakarta: Ministry of Education and Culture Project to Improve Teacher Quality Equivalent to D II and Population Division.

Djamarah, Zain. (2011). Teaching and Learning Strategies. Jakarta: Rineka Cipta

Elizabeth. B. Hurlock. (1995). Developmental Psychology. Fifth Edition. Jakarta: Erlangga.

Heri Rahyubi. (2012). Learning Theories and Motor Learning Applications. Bandung: Nusa Media.

Imam Soedjadi. (1979). Games and Methods Book I. Jakarta: Ministry of Education and Culture.

Imam Soedjadi. (1979). Games and Methods Book II. Jakarta: Ministry of Education and Culture.

Isjoni. (2010). Cooperative Learning Improves Intelligence Between Learners. Yogyakarta: Student Library.

John W. Santrock. (2010). Educational Psychology. Sarah Genis B.University Of Texas at Dallas Translation.

Kosasih, E. (1992). Sports Techniques and Exercise Programs. Jakarta: AKA Press.

Megawangi, R. et al. (2005). Appropriate and Enjoyable Education: Application of Depelovmentally Appropriate Practice (DAP) Theory. Depok: Indonesian Heritage Foundation. 
Muchtar, I., Kartiko, D.C., and Tuasikal, A.R. (2020). Development of a Long Jump Education Model through a Game Approach to Improve Basic Movement for Students with Disabilities Grahita in Inclusive Schools at SMP Negeri 28 Surabaya. Budapest International Research and Critics in Linguistics and Education (BirLE) Journal Vol 3 (3): $1479-1488$.

Novi Mulyani. (2016). Super Fun Indonesian Children's Traditional Games. Yogyakarta: DIVA Pres.

Rusli Lutan. (2000). Principles of Physical Education Approaches to Movement Education in Elementary Schools. Jakarta: Directorate General of Sports, Ministry of National Education.

Rusli Lutan, J. Hartanto, Tomolius. (2001). Life-long Orientation Physical Fitness Education. Jakarta: Directorate General of Sports.

Sardiman, AM. (2011). Interaction and Learning Motivation. Jakarta: PT Rajagrafindo Persada 